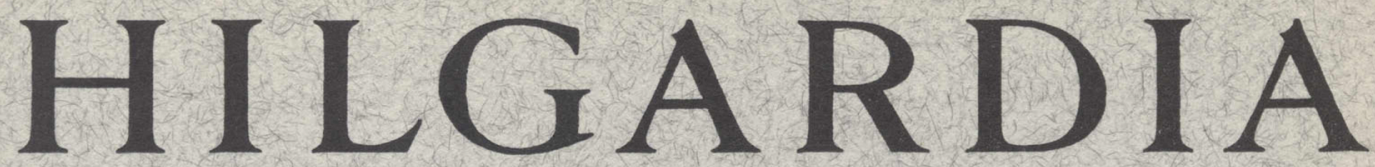

A Journal of Agricultural Science Publisbed by the California Agricultural Experiment Station

\title{
EFFECT OF GIBBERELLIN ON VINE BEHAVIOR AND CROP PRODUCTION IN SEEDED AND SEEDLESS VITIS VINIFERA
}

\author{
ROBERT J. WEAVER \\ and \\ STANLEY B. MCCUNE
}

UNIVERSITY OF CALIFORNIA - BERKELEY, CALIFORNIA 
In 1957, vines of Zinfandel, Red Malaga, Tokay, and Ribier grapes were sprayed, at four developmental stages, with gibberellin in a range of 0 to $25 \mathrm{ppm}$. In the spring of 1958 , certain seeded varieties showed severe injury as a result of the higher concentrations of gibberellin. In 1958 and 1959, therefore, those experiments were followed up with the work reported in the present study, designed to determine the degree of recovery in vines injured by gibberellin.

Cropping, vine vigor, and spring foliation were studied as indicators of recovery. Results showed that two seasons were usually required for vines to return to normal crop weights, pruning brush weights, spring foliation, and cluster counts.

Experiments with seedless grapes-Thompson Seedless and Black Corinth-showed no injury to these varieties at concentrations of gibberellin as high as $100 \mathrm{ppm}$. (In one instance, a Thompson Seedless vine was sprayed at $1,000 \mathrm{ppm}$ in two consecutive years, with no apparent damaging effect.) Thus, gibberellin proved very toxic to the seeded grapes studied, but nontoxic to the seedless.

Little or no change in percentage of sugar or starch occurred in either seeded or seedless varieties, as determined by carbohydrate analysis of basal portions of canes during dormancy. 


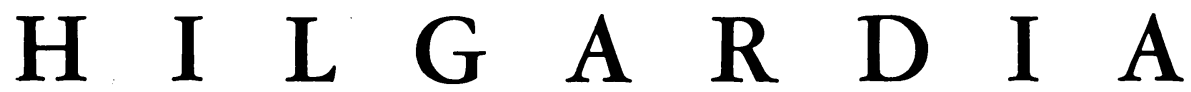

A Journal of Agricultural Science Published by

the California Agricultural Experiment Station

\section{EFFECT OF GIBBERELLIN ON VINE BEHAVIOR AND CROP PRODUCTION IN SEEDED AND SEEDLESS VITIS VINIFERA ${ }^{1,2}$}

\author{
ROBERT J. WEAVER ${ }^{3}$ and STANLEY B. MCCUNE 4
}

\section{INTRODUCTION}

THE FIRST GIBBERELLIN spray experiments on grapes conducted at the University of California were at Davis in 1957 (Weaver, 1957; Weaver and McCune, 1959a). ${ }^{5}$ This early work, on both seedless and seeded grapes, was designed to determine the effects of gibberellin on set of fruit, berry size, elongation of cluster parts, composition of the fruit, and vegetative growth. In the spring of 1958, certain seeded varieties showed severe injury-delayed foliation and killing of buds-as a result of gibberellin at the higher concentrations applied in the previous season. The experiments were therefore continued for two more seasons, to measure the damage from the various treatments and to see whether the vines would return to normal production. Vine vigor was measured in terms of pruning brush weight, and delay in foliation was determined from shoot counts in the spring. In certain instances the study of vine vigor was supplemented with determinations of starch and sugar content of the canes in the dormant season, and in one instance cluster frameworks were analyzed. Yields were determined on the basis of cluster counts in the spring and crop weights in the fall.

Another set of experiments was initiated in 1958 (Weaver and McCune, $1959 b, c)$ and carried on through the season of 1959. In still other experiments, vines were sprayed in successive years with various concentrations to assess the possibility of cumulative injury.

Varietal differences in sensitivity to gibberellin were great, especially between the seeded and the seedless varieties. Those differences were further explored.

${ }^{1}$ Submitted for publication June 17, 1960.

2 This work was supported in part by grants from Merck and Co., Inc., Rahway, New Jersey, and from the Abbott Laboratories, North Chicago, Illinois.

${ }^{3}$ Lecturer in Viticulture and Viticulturist in the Experiment Station, Davis.

" Senior Laboratory Technician in the Department of Viticulture and Enology, Davis.

"See "Literature Cited" for citations referred to in the text by author and date. 
In these early experiments, the concentrations of gibberellin were often much higher than is now known to be commercially feasible. Nevertheless, the results are of both physiological and practical interest in the study of recovery of injured vines.

Earlier publications have presented results obtained in the first growing season for most experiments initiated in 1957 and 1958. This paper is concerned mainly with results following the first season. Experimental methods and results of the first seasons are reviewed only briefly.

\section{MATERIALS AND METHODS}

The experimental vines were those of mature Thompson Seedless (Sultanina), Black Corinth, Zinfandel, Carignane, Red Malaga, Tokay, and Ribier in the irrigated vineyard of the University of California at Davis. Black Corinth, a raisin grape, and Thompson Seedless, treated as a table grape in these experiments, were usually pruned to four canes (Winkler, 1931). Zinfandel and Carignane, both wine grapes, were head-trained and spur-pruned. Red Malaga, Tokay, and Ribier, all table grapes, were cordontrained and spur-pruned.

Spraying was done with 3-gallon sprayers. All concentrations are expressed as parts per million ( $\mathrm{ppm}$ ) on an acid equivalent basis. Dreft was always used as a wetting agent unless otherwise stated. The water-soluble potassium salt of gibberellic acid, containing 80 per cent active ingredient, and supplied by Merck and Co., is herein referred to as gibberellin. At harvest or sampling time the berries were removed from the clusters and thoroughly mixed. Average berry weight was determined by weighing 200 berries in duplicate. The remaining berries were crushed. The percentage of total soluble solids in the juice, determined with a Balling hydrometer, is expressed as degrees Balling. Total acidity was determined by diluting $10 \mathrm{ml}$ of juice to $50 \mathrm{ml}$ with distilled water, and titrating with $0.133 \mathrm{~N} \mathrm{NaOH}$, using phenolphthalein as an indicator. Results are expressed as gm of tartaric acid per $100 \mathrm{ml}$ of juice-about the percentage of the acid in grapes.

Unless stated otherwise, a basal 6-inch segment was removed for carbohydrate analysis. Extraction procedures used by Winkler and Williams (1945) were followed except that a 0.5 per cent solution of Clarase was used for starch digestion. Sugar determinations were run according to the method of Phillips (1941). Analytical data are expressed as percentage values on a dry-weight basis.

\section{EFFECT OF GIBBERELLIN ON SEEDED GRAPES}

\section{Experiments Begun in 1957}

These experiments were on Zinfandel, Red Malaga, Tokay, and Ribier (Weaver and McCune, 1959a). Vines were sprayed with gibberellin in concentrations of $0,0.1,1.0,5.0$, and $25.0 \mathrm{ppm}$ at one of four developmental stages: (1) when shoots were 3 to 9 inches long and clusters were $1 / 2$ to $11 / 2$ inches long; (2) at "full bloom" (when 70 per cent of the calyptras had fallen); (3) when shatter was complete, following bloom; and (4) when the berries began to color. 
Zinfandel. In 1957, different vines were sprayed at each of the four stages (May 2, June 4, June 11, and July 29). No crop weights were obtained in the first season. Shoots were obtained on December 26 of that year for analysis of carbohydrates in the dormant season. There were no significant differences between treated and untreated vines (table 1).

Pruning brush weights obtained on January 30, 1958, did not differ significantly with differences in concentrations of gibberellin applied in the

TABLE 1

PERCENTAGE OF SUGARS AND STARCH IN ZINFANDEL CANES SPRAYED WITH GIBBERELLIN AT FOUR DIFFERENT DATES IN 1957

(Samples taken on December 26, 1957.)

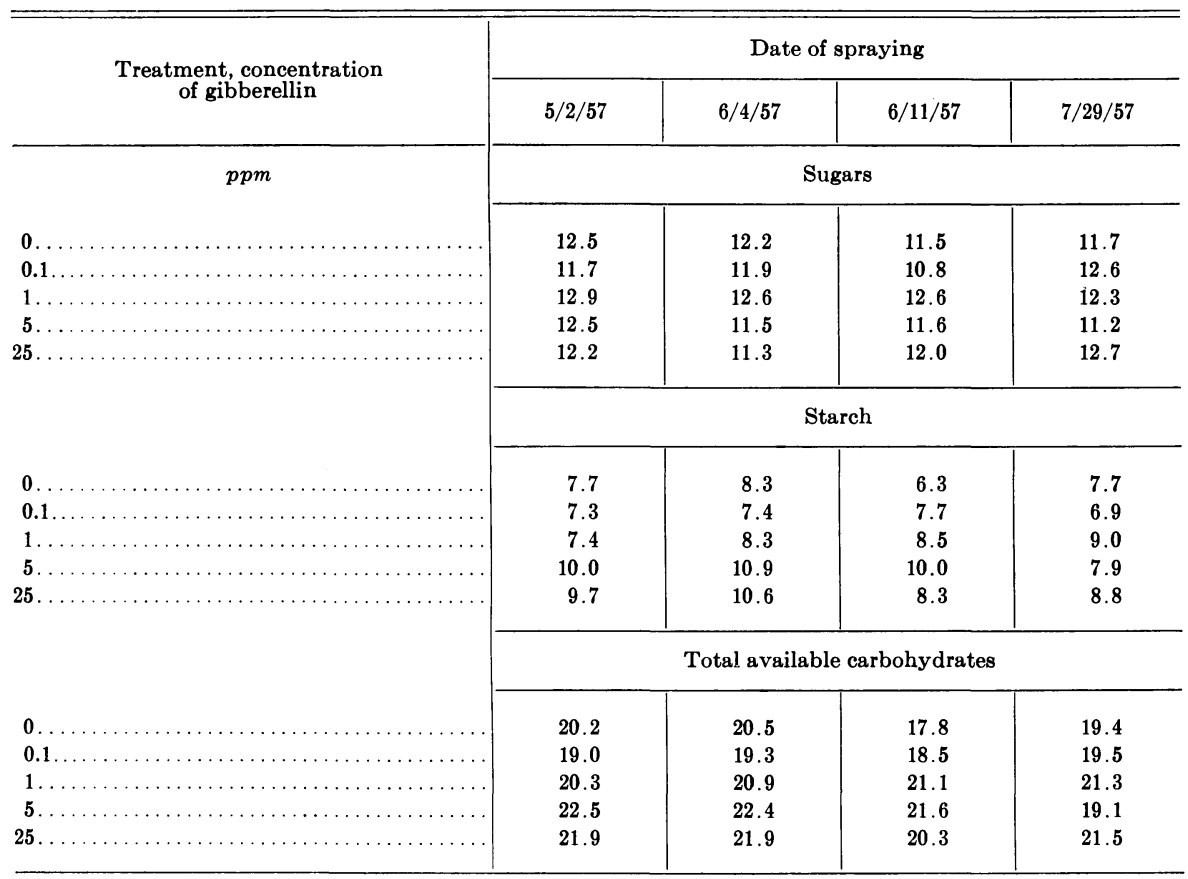

previous year, although they tended to increase, with increasing concentrations, in vines that had received one of the first three sprayings. Cluster counts, made on April 20,1958, were often decreased by the gibberellin application of the previous year, especially in vines of the last three sprayings (table 2). Crop weights on September 8, 1958, indicate that gibberellin at 5 and $25 \mathrm{ppm}$ decreased crop weight on vines of the first spraying, although the differences were not significant. Variation of crop on the control vines appeared to be that normally encountered in the grapevine.

Brush weights taken in the second year following the spray applications (March 13, 1959) often increased with the concentration of gibberellin applied in the last three sprayings in 1957 (table 2). Cluster counts on April 30, 1959, showed no significant difference between treated and control 


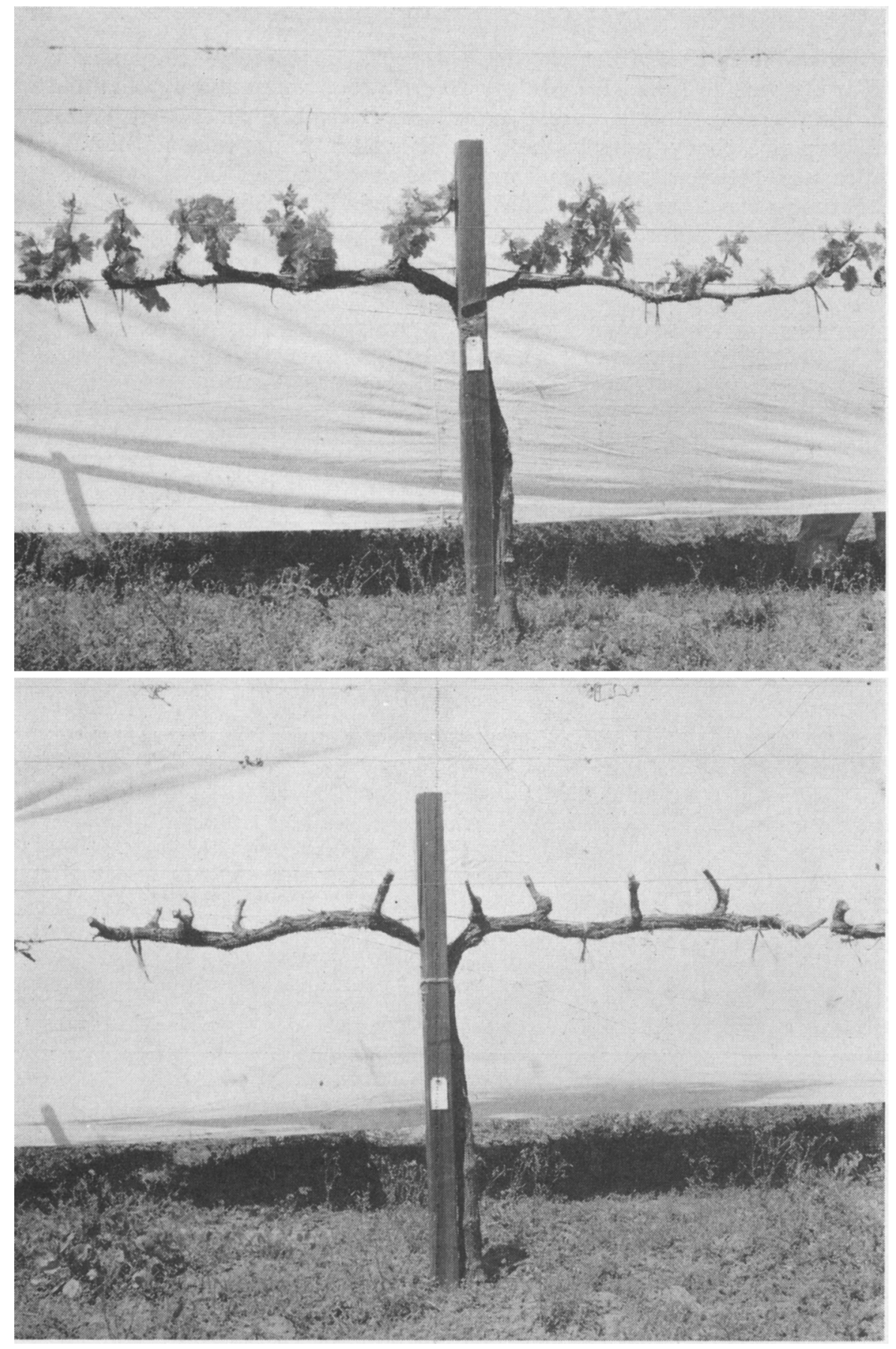

Fig. 1. Red Malaga vine (lower) in the spring of 1958 after spraying on June 4, 1957, with gibberellin at $25 \mathrm{ppm}$. Note that spurs of control vine (upper) have young shoots 6 to 8 inches long, but that buds of sprayed vine (lower) have not yet grown. (Photographed April 24, 1958.) 
TABLE 2

PRUNING WEIGHTS, CLUSTER COUNTS, AND CROP WEIGHTS FOR ZINFANDEL VINES TREATED IN 1957 WITH GIBBERELLIN AT VARIOUS CONCENTRATIONS ON VARIOUS DATES (Figures are averages of five replicate vines.)

\begin{tabular}{|c|c|c|c|c|c|c|c|c|}
\hline \multirow{3}{*}{$\begin{array}{l}\text { Treatment, } \\
\text { concentration of } \\
\text { gibberellin }\end{array}$} & \multicolumn{8}{|c|}{ Date of spraying } \\
\hline & \multicolumn{2}{|c|}{$5 / 2 / 57$} & \multicolumn{2}{|c|}{$6 / 4 / 57$} & \multicolumn{2}{|c|}{$6 / 11 / 57$} & \multicolumn{2}{|c|}{$7 / 29 / 57$} \\
\hline & 1958 & 1959 & 1958 & 1959 & 1958 & 1959 & 1958 & 1959 \\
\hline 0 . & 2.5 & 2.9 & 3.6 & 2.6 & 3.0 & 3.3 & 3.7 & 2.4 \\
\hline 0.1 . & 2.8 & 3.1 & 4.1 & 3.1 & 3.0 & 2.5 & 3.1 & 2.6 \\
\hline $1 \ldots$ & 3.1 & 2.6 & 3.5 & 2.5 & 3.9 & 2.6 & 2.8 & 2.8 \\
\hline 5... & 3.4 & 2.8 & 4.5 & 3.1 & 3.3 & 3.6 & 3.2 & 2.9 \\
\hline
\end{tabular}

*L.S.D. at 5 per cent in 1958 is N.S.. in $1959,0.6$.

$\rightarrow$ L.S.D. at 5 per cent in 1958 is 0.5 , in 1959 , N.S.

\begin{tabular}{|c|c|c|c|c|c|c|c|c|}
\hline 0. & 32 & 26 & 41 & 20 & 37 & 30 & 46 & 19 \\
\hline $0.1 \ldots$ & 31 & 26 & 35 & 15 & 38 & 24 & 43 & 26 \\
\hline $1 \ldots \ldots \ldots$ & 27 & 29 & 34 & 21 & 28 & 20 & 43 & 16 \\
\hline $5 \ldots$ & 36 & 32 & 38 & 20 & 24 & 20 & 31 & 23 \\
\hline
\end{tabular}

* L.S.D. at 5 per cent in 1958 is 4.3 , in 1959 , N.S.

$\dagger$ L.S.D. at 5 per cent in 1958 is 3.4 , in 1959 , N.S.

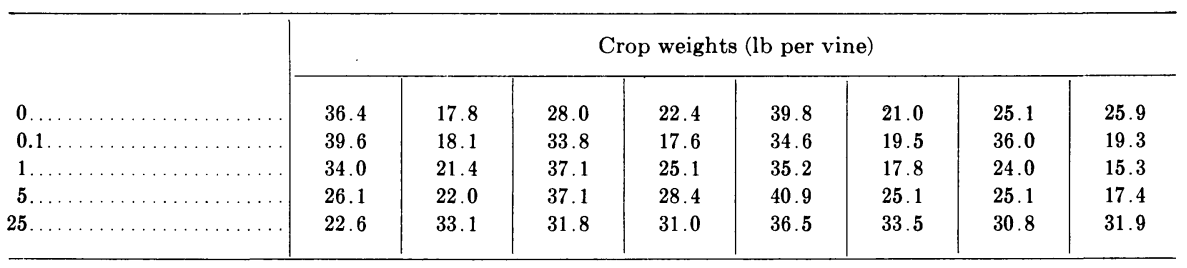

*L.S.D. at 5 per cent in 1958 is N.S., in $1959,3.7$.

†L.S.D. at 5 per cent in 1958 is 5.4 , in 1959 , N.S.

* Difference required for significance at the 5 per cent level between concentrations on a given spraying date. $\dagger$ Difference required for significance between spraying dates at a given concentration.

vines. Crop weights taken on September 26, 1959, usually showed a general increase on vines that had received 5 or $25 \mathrm{ppm}$ gibberellin in 1957. Thus, the vines appeared to have recovered from the injury caused by the 1957 applications.

Red Malaga. Vines were sprayed on May 3, June 4, June 14, and July 29, 1957 (Weaver and McCune, 1959a). Pruning brush weights taken on March 5,1958 , were usually increased by the first two sprayings and by the compound at $25 \mathrm{ppm}$ on the third spraying date (table 3). Counts on April 18, 1958 , showed that gibberellin at $25 \mathrm{ppm}$ sprayed at the first three dates had 
TABLE 3

PRUNING WEIGHTS, SHOOT COUNTS, CLUSTER COUNTS, AND CROP WEIGHTS FOR RED MALAGA GRAPES TREATED WITH GIBBERELLIN IN 1957 ON VARIOUS DATES AND WITH VARIOUS CONCENTRATIONS

(Figures are averages of four replicate vines.)

\begin{tabular}{|c|c|c|c|c|c|c|c|c|}
\hline \multirow{3}{*}{$\begin{array}{l}\text { Treatment, } \\
\text { concentration of } \\
\text { gibberellin }\end{array}$} & \multicolumn{8}{|c|}{ Date of spraying } \\
\hline & \multicolumn{2}{|c|}{$5 / 3 / 57$} & \multicolumn{2}{|c|}{$6 / 4 / 57$} & \multicolumn{2}{|c|}{$6 / 14 / 57$} & \multicolumn{2}{|c|}{$7 / 29 / 57$} \\
\hline & 1958 & 1959 & 1958 & 1959 & 1958 & 1959 & 1958 & 1959 \\
\hline ppm & \multicolumn{8}{|c|}{ Pruning weights (lb per vine) } \\
\hline $0 \ldots$ & 7.5 & 6.4 & 8.0 & 8.1 & 7.4 & 5.9 & 9.4 & 7.0 \\
\hline 0.1 . & 9.1 & 8.0 & 8.5 & 8.3 & 8.3 & 5.1 & 9.0 & 7.4 \\
\hline 1. & 8.3 & 8.4 & 10.9 & 6.5 & 7.4 & 8.1 & 8.0 & 7.9 \\
\hline & 9.0 & 4.9 & 10.3 & 6.9 & 7.6 & 6.3 & 8.9 & 7.8 \\
\hline $25 \ldots \ldots \ldots \ldots \ldots$ & 9.1 & 6.5 & 11.0 & 6.9 & 10.3 & 6.4 & 9.0 & 6.4 \\
\hline
\end{tabular}

${ }^{*}$ L.S.D. at 5 per cent in 1958 is 1.1 , in 1959 , N.S.

HL.S.D. at 5 per cent in 1958 and 1959 is N.S.

\begin{tabular}{|c|c|c|c|c|c|c|c|c|}
\hline 0. & 18.8 & 26.0 & 26.8 & 22.0 & 25.8 & 24.0 & $\ldots$ & 18.0 \\
\hline $0.1 \ldots \ldots$ & 21.5 & 24.0 & 24.3 & 27.0 & 23.3 & 23.0 & $\ldots$ & 25.0 \\
\hline $1 \ldots \ldots \ldots$ & 22.5 & 26.0 & 22.8 & 24.0 & 30.0 & 30.0 & $\ldots$ & 25.0 \\
\hline $5 \ldots$ & 17.8 & 24.0 & 20.3 & 21.0 & 25.3 & 20.0 & $\ldots$ & 25.0 \\
\hline
\end{tabular}

${ }^{*}$ L.S.D. at 5 per cent in 1958 is 5.3 , in 1959 , N.S.

$\uparrow$ L.S.D. at 5 per cent in 1958 is 2.6 , in 1959 , N.S.

\begin{tabular}{|c|c|c|c|c|c|c|c|c|}
\hline 0 . & \multicolumn{8}{|c|}{ Cluster counts (no. per vine) } \\
\hline $0.1 \ldots$ & 18 & 13 & 19 & 16 & 16 & 13 & 17 & 11 \\
\hline $1 \ldots$ & 15 & 10 & 17 & 12 & 19 & 14 & 14 & 11 \\
\hline 5. & 20 & 14 & 6 & 8 & 9 & 11 & 18 & 17 \\
\hline
\end{tabular}

${ }^{*}$ L.S.D. at 5 per cent in 1958 is 3.9 , in 1959 , N.S.

$\dagger$ L.S.D. at 5 per cent in 1958 is 3.1 , in 1959 , N.S.

\begin{tabular}{|c|c|c|c|c|c|c|c|c|}
\hline 0. & 23.5 & 15.1 & 30.2 & 16.3 & 27.0 & 16.6 & 26.8 & 15.3 \\
\hline 0.1 . & 32.2 & 17.3 & 27.9 & 18.9 & 27.1 & 13.8 & 21.2 & 21.8 \\
\hline 1. & 23.5 & 11.1 & 24.9 & 12.3 & 22.0 & 18.4 & 23.8 & 12.0 \\
\hline $5 \ldots$ & 24.9 & 20.0 & 12.4 & 11.8 & 19.3 & 17.5 & 32.2 & 24.5 \\
\hline
\end{tabular}

${ }^{*}$ L.S.D. at 5 per cent in 1958 is 8.5 , in $1959,4.0$.

L.S.D. at 5 per cent in 1958 is 4.3 , in 1959 , N.S.

* Difference required for significance between concentrations on a given spraying date.

$\dagger$ Difference required for significance between spraying dates at a given concentration. 
TABLE 4

PRUNING WEIGHTS, SHOOT COUNTS, CLUSTER COUNTS, AND CROP WEIGHTS OF TOKAY GRAPES TREATED WITH GIBBERELLIN IN 1957 ON VARIOUS DATES AND WITH VARIOUS CONCENTRATIONS (Figures are averages of four replicate vines.)

\begin{tabular}{|c|c|c|c|c|c|c|}
\hline \multirow{3}{*}{$\begin{array}{c}\text { Treatment, concentration } \\
\text { of gibberellin }\end{array}$} & \multicolumn{6}{|c|}{ Date of spraying } \\
\hline & \multicolumn{2}{|c|}{$6 / 6 / 57$} & \multicolumn{2}{|c|}{$6 / 14 / 57$} & \multicolumn{2}{|c|}{$8 / 7 / 57$} \\
\hline & 1958 & 1959 & 1958 & 1959 & 1958 & 1959 \\
\hline ppm & \multicolumn{6}{|c|}{ Pruning weight (lb per vine) } \\
\hline 0 . & 6.8 & 3.1 & 6.5 & 4.5 & 6.9 & 4.1 \\
\hline 0.1 . & 6.1 & 2.5 & 6.5 & 3.9 & 6.5 & 3.3 \\
\hline 1. & 7.4 & 4.1 & 6.8 & 4.1 & 6.0 & 3.8 \\
\hline 5 . & 6.9 & 4.3 & 6.7 & 6.3 & 5.8 & 2.4 \\
\hline $25 \ldots$ & 9.5 & 7.5 & 7.0 & 6.0 & 5.5 & 1.8 \\
\hline
\end{tabular}

${ }^{\star}$ L.S.D. at 5 per cent in 1958 and 1959 is N.S.

HL.S.D. at 5 per cent in 1958 is 1.0 , in $1959,0.9$.

\begin{tabular}{|c|c|c|c|c|c|c|}
\hline \multirow[b]{2}{*}{0} & \multicolumn{6}{|c|}{ Shoot counts (no. per vine) } \\
\hline & .. & 20 & .. & 22 & $\ldots$ & .. \\
\hline 0.1 & . & 21 & .. & 23 & . & . \\
\hline $1 \ldots$ & . & 22 & .. & 25 & .. & . \\
\hline $5 \ldots \ldots \ldots \ldots \ldots \ldots \ldots \ldots \ldots \ldots$ & . & 23 & .. & 27 & . & . \\
\hline $25 \ldots \ldots \ldots \ldots \ldots \ldots \ldots \ldots \ldots \ldots$ & . & 22 & . & 22 & . & . \\
\hline
\end{tabular}

*L.S.D. at 5 per cent in 1959 is N.S.

L.S.D. at 5 per cent in 1959 is N.S.

\begin{tabular}{|c|c|c|c|c|c|c|}
\hline \multirow[b]{2}{*}{0.} & \multicolumn{6}{|c|}{ Cluster counts (no. per vine) } \\
\hline & 34 & 28 & 17 & 33 & .. & .. \\
\hline $0.1 \ldots \ldots \ldots \ldots \ldots \ldots \ldots$ & 31 & 32 & 28 & 37 & . & .. \\
\hline $1 \ldots \ldots \ldots \ldots \ldots \ldots \ldots \ldots \ldots \ldots \ldots \ldots \ldots \ldots \ldots$ & 21 & 28 & 17 & 36 & .. & .. \\
\hline $\mathbf{5} \ldots \ldots \ldots \ldots \ldots \ldots \ldots \ldots$ & 12 & 33 & 15 & 37 & . & .. \\
\hline $25 \ldots \ldots \ldots \ldots \ldots \ldots \ldots \ldots \ldots \ldots \ldots \ldots \ldots \ldots \ldots \ldots \ldots$ & 4 & 25 & 9 & 28 & .. & .. \\
\hline
\end{tabular}

${ }^{*}$ L.S.D. at 5 per cent in 1958 is 5.5 , in 1959 , N.S. H.S.D. at 5 per cent in 1958 is 3.8 , in 1959 , N.S.

\begin{tabular}{|c|c|c|c|c|c|c|}
\hline \multirow[b]{2}{*}{0.} & \multicolumn{6}{|c|}{ Crop weights (lb per vine) } \\
\hline & 64.3 & 43.3 & 41.3 & 49.6 & 59.3 & 54.8 \\
\hline 0.1. & 60.5 & 44.4 & 55.5 & 56.1 & 48.5 & 45.0 \\
\hline $1 \ldots$ & 43.5 & 39.6 & 50.1 & 59.1 & 52.5 & 51.1 \\
\hline $5 \ldots \ldots \ldots$ & 41.0 & 55.4 & 47.0 & 62.4 & 49.8 & 48.5 \\
\hline $25 \ldots \ldots \ldots \ldots \ldots \ldots \ldots \ldots \ldots \ldots$ & 17.8 & 64.5 & 26.0 & 61.5 & 53.3 & 43.0 \\
\hline
\end{tabular}

*L.S.D. at 5 per cent in 1958 is 10.4 , in 1959 , N.S.

TL.S.D. at 5 per cent in 1958 is 7.6 , in $1959,7.0$.

* Difference required for significance between concentrations on a given spraying date.

$\dagger$ Difference required for significance between spraying dates at a given concentration. 
TABLE 5

PRUNING WEIGHTS, SHOOT COUNTS, CLUSTER COUNTS, AND CROP WEIGHTS OF RIBIER GRAPES TREATED WITH GIBBERELLIN IN 1957 ON VARIOUS DATES AND WITH VARIOUS CONCENTRATIONS (Figures are averages of four replicate vines.)

\begin{tabular}{|c|c|c|c|c|c|c|c|c|}
\hline \multirow{3}{*}{$\begin{array}{l}\text { Treatment, } \\
\text { concentration of } \\
\text { gibberellin }\end{array}$} & \multicolumn{8}{|c|}{ Date of spraying } \\
\hline & \multicolumn{2}{|c|}{$5 / 6 / 57$} & \multicolumn{2}{|c|}{$5 / 27 / 57$} & \multicolumn{2}{|c|}{$6 / 11 / 57$} & \multicolumn{2}{|c|}{$8 / 7 / 57$} \\
\hline & 1958 & 1959 & 1958 & 1959 & 1958 & 1959 & 1958 & 1959 \\
\hline$p p m$ & \multicolumn{8}{|c|}{ Pruning weights (lb per vine) } \\
\hline $0 \ldots \ldots$ & 5.3 & 3.6 & 5.0 & 5.1 & 4.6 & 4.4 & 4.3 & 7.1 \\
\hline 0.1 . & 5.8 & 5.6 & 4.5 & 3.9 & 4.9 & 4.6 & 5.6 & 4.5 \\
\hline 1. & 6.8 & 5.5 & 5.9 & 5.8 & 5.3 & 5.4 & 5.0 & 4.4 \\
\hline $5 \ldots$ & 4.9 & 4.4 & 9.5 & 8.1 & 5.8 & 4.9 & 4.5 & 3.4 \\
\hline $25 \ldots \ldots \ldots \ldots \ldots \ldots$ & 9.4 & 6.0 & 7.5 & 6.9 & 6.6 & 6.3 & 4.9 & 4.6 \\
\hline
\end{tabular}

* L.S.D. at 5 per cent in 1958 is 1.2 , in 1959 , N.S.

†.S.D. at 5 per cent in 1958 and 1959 is N.S.

\begin{tabular}{|c|c|c|c|c|c|c|c|c|}
\hline \multirow{2}{*}{$\begin{array}{l}0 \ldots \ldots \ldots \ldots \ldots \ldots \ldots \\
0.1 \ldots \ldots \ldots \ldots \ldots \ldots\end{array}$} & $\ldots$ & 23 & $\ldots$ & 27 & $\ldots$ & 24 & $\ldots$ & $\ldots$ \\
\hline & . & 28 & $\cdots$ & 23 & . & 26 & $\cdots$ & . \\
\hline $1 \ldots \ldots \ldots \ldots \ldots \ldots$ & . & 24 & . & 31 & . & 24 & . & . \\
\hline $\boldsymbol{5} \ldots \ldots \ldots$ & $\cdots$ & 26 & . & 26 & $\cdots$ & 24 & $\cdots$ & . \\
\hline
\end{tabular}

* L.S.D. at 5 per cent in 1959 is N.S.

H.S.D. at 5 per cent in 1959 is N.S.

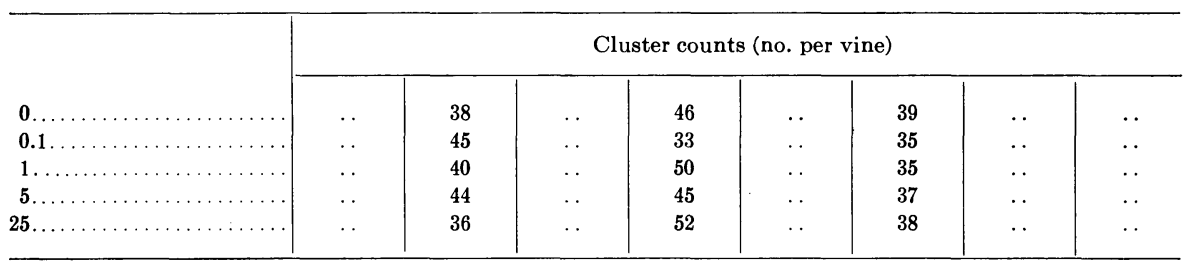

${ }^{*}$ L.S.D. at 5 per cent in 1959 is N.S.

$\leftarrow$ L.S.D. at 5 per cent in 1959 is N.S.

\begin{tabular}{|c|c|c|c|c|c|c|c|c|}
\hline \multirow[b]{2}{*}{0.} & \multicolumn{8}{|c|}{ Crop weights (lb per vine) } \\
\hline & 48.7 & 39.9 & 35.5 & 37.5 & 41.0 & 39.5 & 31.3 & 52.9 \\
\hline 0.1 . & 28.7 & 44.1 & 28.9 & 31.8 & 20.9 & 16.6 & 32.0 & 48.1 \\
\hline $1 .$. & 37.7 & 39.0 & 20.9 & 37.9 & 27.3 & 30.0 & 26.2 & 46.0 \\
\hline 5. & 23.8 & 34.8 & 22.5 & 30.6 & 29.3 & 37.5 & 42.1 & 52.8 \\
\hline 25 . & 15.4 & 34.5 & 13.2 & 39.3 & 18.7 & 28.3 & 42.1 & 57.8 \\
\hline
\end{tabular}

${ }^{*}$ L.S D. at 5 per cent in 1958 and 1959 is N.S.

$\dagger$ L.S.D. at 5 per cent in 1958 is N.S., in $1959,10.6$.

* Difference required for significance between concentrations on a given spraying date.

+ Difference required for significance between spraying dates at a given concentration. 
markedly reduced both shoots and clusters, and that gibberellin at $5 \mathrm{ppm}$, sprayed at the second date, had significantly reduced shoot and cluster counts (table 3, fig. 1). The compound sprayed at $5 \mathrm{ppm}$ on the third date of treatment reduced the cluster count. The primary buds on sprayed vines were often dead, but the two lateral buds had often developed.

Crop weights on October 21, 1958, showed that gibberellin at 5 and 25 ppm usually reduced the crop markedly on vines of all but the last spraying. Some sprayed vines had almost no fruit.

In 1959, brush weights on March 14 showed little difference between control and treated vines. Shoot and cluster counts on April 23 showed that vines sprayed in 1957 had usually completely recovered. Crop weights on September 25, while erratic, showed that sprayed vines often had larger crops than the controls. In five out of six instances in which a significant increase had occurred, sprays had been applied at 5 or $25 \mathrm{ppm}$.

Tokay. Sprayings were on June 6, June 14, and August 7, 1957 (table 4). (The earliest spraying was omitted.) Pruning weights were obtained on March 5, 1958. Differences were not significant, but there was a tendency for an increase from the first spraying, and a decrease from the last. Cluster counts on April 18, 1958, showed that $25 \mathrm{ppm}$ greatly reduced the number of clusters on vines of the first two sprayings, the reduction being especially large from the first, even at $1 \mathrm{ppm}$. Crop weights, obtained on September 8 , 1958 , were greatly decreased by gibberellin applied at $25 \mathrm{ppm}$ in the first two sprayings. The first spraying showed a decrease as the concentration of gibberellin increased. The last spraying usually had little effect on crop weight.

Pruning weights on March 14, 1959, showed no significant differences between concentrations. On April 20, 1959, shoot and cluster counts of all sprayed vines were normal. Weight of crop was taken on September 27, 1959. There were no significant differences between treated and control fruit, although gibberellin usually tended to increase the crop weight in vines of the first and second sprayings (table 4).

Ribier. Vines were sprayed on May 6, May 27, June 11, and August 7, 1957 (table 5). Brush weights were obtained on March 7, 1958. Vines of the first three sprayings usually showed a gradual increase in weight as gibberellin concentration increased. The data obtained on October 21, 1958, indicate that all concentrations of gibberellin except for the last spraying decreased crop weights, but not significantly. Crop weights in Ribier varied considerably in this experiment in 1958.

On March 16, 1959, pruning brush weights were obtained. The first three sprayings appeared to increase weight, and the last spraying appeared to decrease it. Shoot counts on April 15 and cluster counts on April 23, 1959, showed that sprayed vines had returned to normal.

\section{Experiments Begun in 1958}

Results of these experiments, for 1958, including crop weights, have been published (Weaver and McCune, 1959b). The behavior of the vines was followed during 1959.

Zinfandel. In 1958, different vines at six stages of development were 
TABLE 6

AVERAGE CROP WEIGHT (LB) PER VINE FOR ZINFANDEL GRAPES TREATED WITH GIBBERELLIN IN 1958 ON VARIOUS DATES

AND AT VARIOUS CONCENTRATIONS

(Fruit harvested in the fall of 1958 and 1959. Figures for first four sprayings are averages of five replicate vines and for the last two, averages of four replicate vines.)

\begin{tabular}{|c|c|c|c|c|c|c|c|c|c|c|c|c|}
\hline \multirow{3}{*}{$\begin{array}{l}\text { Treat- } \\
\text { ment, } \\
\text { concen- } \\
\text { tration } \\
\text { of } \\
\text { gibber- } \\
\text { ellin }\end{array}$} & \multicolumn{12}{|c|}{ Date of spraying } \\
\hline & \multicolumn{2}{|c|}{$4 / 15 / 58$} & \multicolumn{2}{|c|}{$4 / 28 / 58$} & \multicolumn{2}{|c|}{$5 / 9 / 58$} & \multicolumn{2}{|c|}{$5 / 19 / 58$} & \multicolumn{2}{|c|}{$5 / 28 / 58$} & \multicolumn{2}{|c|}{$6 / 9 / 58$} \\
\hline & 1958 & 1959 & 1958 & 1959 & 1958 & 1959 & 1958 & 1959 & 1958 & 1959 & 1958 & 1959 \\
\hline$p p m$ & & & & & & & & & & & & \\
\hline $0 \ldots$ & 48.7 & 23.7 & 33.7 & 24.3 & 44.6 & 23.5 & 36.9 & 17.5 & 23.6 & 34.5 & 28.3 & 41.0 \\
\hline $1 \ldots \ldots$ & $\ldots$ & $\ldots$ & $\ldots$ & $\ldots$ & $\ldots$ & $\ldots$ & $\ldots$ & $\ldots$ & 37.8 & 38.5 & 19.8 & 36.0 \\
\hline $5 \ldots \ldots$ & $\ldots$ & $\ldots$ & $\ldots$ & $\ldots$ & $\ldots$ & $\ldots$ & $\ldots$ & $\ldots$ & 35.0 & 40.1 & 26.1 & 43.6 \\
\hline $10 \ldots \ldots$ & 45.8 & 16.3 & 38.9 & 21.2 & 31.6 & 27.8 & 31.5 & 22.8 & $\ldots$ & $\ldots$ & $\ldots$ & $\ldots$ \\
\hline $25 \ldots \ldots$ & 39.3 & 15.8 & 37.0 & 16.8 & 34.2 & 24.6 & 31.2 & 23.4 & 37.6 & 35.6 & 32.9 & 33.5 \\
\hline $50 \ldots \ldots$ & 25.5 & 18.3 & 30.2 & 20.8 & 24.3 & 22.2 & 22.6 & 15.2 & 24.6 & 30.9 & 14.9 & 33.3 \\
\hline
\end{tabular}

L.S.D. at 5 per cent for concentrations at a given spraving date: 1958, sprayings 1 through $4,12.1$ $\mathrm{lb}$; sprayings 5 and $6,8.1 \mathrm{lb} .1959$, all sprayings, N.S.

L.S.D. at 5 per cent for spraying dates at a given concentration: 1958 , sprayings 1 through $4,4.3$ $\mathrm{lb}$; sprayings 5 and $6,3.8 \mathrm{lb}$. 1959 , sprayings 1 through $4,5.1 \mathrm{lb}$; sprayings 5 and 6 , N.S.

\section{TABLE 7}

PRUNING WEIGHTS PER VINE FOR ZINFANDEL GRAPES TREATED IN 1958 WITH GIBBERELLIN AT VARIOUS CONCENTRATIONS

$$
\text { AND ON VARIOUS DATES }
$$

(Vines pruned February 4, 1959. Figures for first four sprayings are averages of five replicate vines, and for the last two, averages of four replicate vines.)

\begin{tabular}{|c|c|c|c|c|c|c|}
\hline \multirow{2}{*}{$\begin{array}{c}\text { Treatment, concentration } \\
\text { of gibberellin }\end{array}$} & \multicolumn{6}{|c|}{ Date of spraying } \\
\hline & $4 / 15 / 58$ & $4 / 28 / 58$ & $5 / 9 / 58$ & $5 / 19 / 58$ & $5 / 28 / 58$ & $6 / 9 / 58$ \\
\hline ppm & $l b$ & $l b$ & $l b$ & $l b$ & $l b$ & $l b$ \\
\hline $\mathbf{0} \ldots \ldots \ldots \ldots \ldots \ldots \ldots \ldots$ & 3.50 & 3.10 & 3.60 & 3.20 & 1.88 & 4.00 \\
\hline $1 \ldots \ldots \ldots \ldots \ldots \ldots \ldots \ldots$ & $\ldots$ & $\ldots$ & $\ldots$ & $\ldots$ & 3.88 & 2.13 \\
\hline $\mathbf{5} \ldots \ldots \ldots \ldots \ldots \ldots \ldots \ldots \ldots$ & $\cdots$ & $\ldots$ & $\ldots$ & $\ldots$ & 4.38 & 3.00 \\
\hline 10. & 3.60 & 3.70 & 4.10 & 4.00 & $\ldots$ & $\ldots$ \\
\hline 25 . & 3.50 & 3.60 & 5.20 & 4.50 & 5.25 & 2.25 \\
\hline$\ldots \ldots \ldots \ldots$ & 4.00 & 5.30 & 4.80 & 4.50 & 4.50 & 1.63 \\
\hline
\end{tabular}

L.S.D. at 5 per cent for concentrations at a given spraying date: sprayings 1 through $4,0.54 \mathrm{lb}$; sprayings 5 and 6 , N.S.

L.S.D. at 5 per cent for spraying dates at a siven concentration: sprayings 1 through $4,0.52 \mathrm{lb}$; sprayings 5 and $6,0.85 \mathrm{lb}$.

sprayed with gibberellin in the range of 0 to $50 \mathrm{ppm}$ (Weaver and McCune, $1959 b$ ). On the date of the first treatment (April 15), shoots were 11/2 to 3 inches long, and clusters were just appearing (some were $1 / 4$ inch long). A second series of vines was sprayed on April 28, when shoots were 7 to 13 inches long and clusters were $11 / 2$ to 3 inches long. On May 9, when a third series of vines was sprayed, many shoots were 22 to 26 inches long, and clusters averaged about 5 inches long. A fourth series of vines was sprayed 
on May 19, when about 50 per cent of the calyptras had fallen. A split-plot experimental design was used.

In another block, Zinfandel vines were given the fifth spray immediately following full bloom (May 28), and a sixth after shatter of berries following bloom, when the berries were 5 to $6 \mathrm{~mm}$ in diameter (June 9).

Fruit on vines was harvested on September 8, 1958 (table 6). Gibberellin at $50 \mathrm{ppm}$ reduced crop yield on vines of all sprayings except the second and fifth. The 1958 harvest figures also showed that there is often a significant difference between spraying dates. This difference between the fifth and sixth spraying dates may be explained by the very low crop weights on vines of the sixth spray at $50 \mathrm{ppm}$.

All vines were pruned on February 4, 1959 (table 7). There was usually more pruning brush on all vines given the first five sprayings. Pruning weights on vines of the last two sprayings were erratic because of the great variation among the controls of the fifth and sixth sprayings at $50 \mathrm{ppm}$.

The newly growing shoots were counted on April 14 and April 20, 1959 (table 8). Shoot growth was greatly retarded except on vines of the fourth and sixth sprayings. By April 20 many more shoots had emerged on treated vines, but usually fewer on those of the first two sprayings than on the controls (table 8).

Fruit was harvested on September 25, 1959 (table 6). Controls and sprayed vines did not differ significantly in yields.

Carignane. Gibberellin was applied (in 1958) at 0,10 , 25, or $50 \mathrm{ppm}$, five vines per treatment, for the first four treatments, and at $0,1,5,25$, or 50 $\mathrm{ppm}$, four vines per treatment, for the last two treatments. The first vines were sprayed on April 15, when average shoot length was about $2 \frac{1}{2}$ inches and cluster length about $3 / 8$ inch. The second series of vines was treated on April 28, when many shoots were 14 to 18 inches long, with the larger clusters $31 / 2$ to 4 inches long. At the third treatment (May 9) many shoots were 24 to 27 inches long, and the clusters 5 inches. A fourth series was sprayed on May 19, when about 2 per cent of the calyptras had fallen, and a fifth on May 28, when almost all calyptras had fallen. The final series was treated on June 9, after the shatter of impotent berries following bloom. A split-plot experimental design was used.

Fruit was harvested on September 25, 1958. Gibberellin usually decreased crop weights. The amount of the decrease was usually greater as the concentration of spray increased (table 9 ).

The rachises of clusters treated with gibberellin at 25 and $50 \mathrm{ppm}$ were very elongated, very tough, and wiry. Carbohydrate analyses were conducted on cluster frameworks of control vines and of vines given gibberellin at $50 \mathrm{ppm}$ in the fourth spraying. On the treated cluster about 70 per cent of the berries were shot berries. All berries were removed from the rachis, and the cluster framework was then thoroughly washed to remove remaining sugar or other residue. Percentages for the control were: sugars, 1.17; starch, 1.79 ; and total carbohydrate, 2.96. Corresponding figures for the sprayed cluster were $2.15,3.06$, and 5.21. Gibberellin increased both the sugar and starch contents of the cluster frameworks. 
TABLE 8

AVERAGE NUMBER OF SHOOTS PER VINE OF ZINFANDEL GRAPES

TREATED IN 1958 WITH GIBBERELLIN AT VARIOUS CONCENTRATIONS AND AT VARIOUS DATES

(Shoots counted April 14 and April 20, 1959. Figures for first four sprayings are averages of five replicate vines, and for the last two, averages of four replicate vines.)

\begin{tabular}{|c|c|c|c|c|c|c|c|c|c|c|c|c|}
\hline \multirow{3}{*}{$\begin{array}{l}\text { Treat- } \\
\text { ment, } \\
\text { concen- } \\
\text { tration } \\
\text { of } \\
\text { gibber- } \\
\text { ellin }\end{array}$} & \multicolumn{12}{|c|}{ Date of spraying } \\
\hline & \multicolumn{2}{|c|}{$4 / 15 / 58$} & \multicolumn{2}{|c|}{$4 / 28 / 58$} & \multicolumn{2}{|c|}{$5 / 9 / 58$} & \multicolumn{2}{|c|}{$5 / 19 / 58$} & \multicolumn{2}{|c|}{$5 / 28 / 58$} & \multicolumn{2}{|c|}{$6 / 9 / 58$} \\
\hline & $4 / 14$ & $4 / 20$ & $4 / 14$ & $4 / 20$ & $4 / 14$ & $4 / 20$ & $4 / 14$ & $4 / 20$ & $4 / 14$ & $4 / 20$ & $4 / 14$ & $4 / 20$ \\
\hline $\begin{array}{c}p p m \\
0 \ldots \ldots\end{array}$ & 9 & 17 & 14 & 22 & 17 & 22 & 9 & 13 & 18 & . & 9 & \\
\hline $1 \ldots \ldots$ & .. & .. & .. & . & . & . & .. & $\ldots$ & 9 & . & 14 & $\ldots$ \\
\hline $5 \ldots \ldots$ & . & .. & .. & .. & .. & . & .. & . & 9 & . & 10 & $\ldots$ \\
\hline $10 \ldots \ldots$ & 2 & 7 & 5 & 14 & 11 & 20 & 11 & 18 & .. & . & $\ldots$ & $\ldots$ \\
\hline $25 \ldots \ldots$ & 1 & 3 & 3 & 9 & 8 & 21 & 8 & 14 & 2 & .. & 4 & $\ldots$ \\
\hline $50 \ldots \ldots$ & 3 & 6 & 2 & 14 & 12 & 22 & 7 & 13 & 3 & .. & 11 & $\ldots$ \\
\hline
\end{tabular}

L.S.D. at 5 per cent for concentrations at a given spraying date: sprayings 1 through 4 counted 4/14/59, 2.7, and counted $4 / 20 / 59,2.8$. Sprayings 5 and 6 counted $4 / 14 / 59,8.8$.

L.S.D. at 5 per cent for spraying dates at a given concentration: sprayings 1 through 4 counted $4 / 14 / 59,2.5$, and counted $4 / 20 / 59,3.3$. Sprayings 5 and 6 counted $4 / 14 / 59$, N.S.

\section{TABLE 9}

AVERAGE CROP WEIGHTS PER VINE FOR CARIGNANE GRAPES IN 1958 AND 1959, AF'TER BEING SPRAYED WITH GIBBERELLIN AT VARIOUS TIMES AND AT VARIOUS CONCENTRATIONS, IN 1958

(Figures for first four sprayings are averages of five replicate vines and for the last two, averages of four replicate vines.)

\begin{tabular}{|c|c|c|c|c|c|c|}
\hline \multirow{2}{*}{$\begin{array}{c}\text { Treatment, concentration } \\
\text { of gibberellin }\end{array}$} & \multicolumn{6}{|c|}{ Date of spraying } \\
\hline & $4 / 15 / 58$ & $4 / 28 / 58$ & $5 / 9 / 58$ & $5 / 19 / 58$ & $5 / 28 / 58$ & $6 / 9 / 58$ \\
\hline \multirow[t]{2}{*}{$p p m$} & \multicolumn{6}{|c|}{ Harvest of 1958} \\
\hline & $l b$ & $l b$ & $l b$ & $l b$ & $l b$ & $l b$ \\
\hline 0 . & 56.1 & 61.0 & 46.0 & 49.5 & 47.5 & 60.9 \\
\hline 1. & $\ldots$ & $\cdots$ & $\ldots$ & $\ldots$ & 44.8 & 57.1 \\
\hline 5.. & $\ldots$ & $\ldots$ & $\ldots$ & $\ldots$ & 43.9 & 54.1 \\
\hline 10. & 53.0 & 52.4 & 49.3 & 39.5 & $\ldots$ & $\ldots$ \\
\hline 25. & 49.1 & 51.8 & 35.6 & 37.6 & 36.5 & 52.4 \\
\hline \multirow[t]{2}{*}{50.} & 43.0 & 52.5 & 29.7 & 24.2 & 41.9 & 49.5 \\
\hline & \multicolumn{6}{|c|}{ Harvest of 1959} \\
\hline $\mathbf{0} \ldots \ldots \ldots$ & 48.5 & 42.0 & 33.0 & 33.0 & 35.0 & 44.3 \\
\hline $1 \ldots \ldots \ldots \ldots$ & $\ldots$ & $\ldots$ & $\ldots$ & $\ldots$ & 37.5 & 42.0 \\
\hline $5 \ldots$ & $\ldots$ & $\cdots$ & $\ldots$ & $\ldots$ & 28.0 & 42.0 \\
\hline 10. & 28.4 & 19.9 & 32.6 & 38.7 & $\ldots$ & $\ldots$ \\
\hline 25 . & 15.5 & 19.5 & 21.1 & 36.9 & 40.9 & 36.3 \\
\hline $50 .$. & 15.4 & 12.8 & 20.4 & 31.9 & 42.4 & 39.0 \\
\hline
\end{tabular}

L.S.D. at 5 per cent for concentrations at a given spraying date: 1958, sprayings 1 through $4,5.5 \mathrm{lb}$; sprayings 5 and 6 , N.S. 1959 , sprayings 1 through $4,6.5 \mathrm{lb}$; sprayings 5 and 6 , N.S.

L.S.D. at 5 per cent for spraying dates at a given concentration: 1958, sprayings 1 through $4,4.3 \mathrm{lb}$; sprayings 5 and $6,4.6 \mathrm{lb}$. 1959 , sprayings 1 through $4,4.4 \mathrm{lb}$; sprayings 5 and 6 , N.S. 
TABLE 10

AVERAGE PRUNING WEIGHTS PER VINE FOR CARIGNANE GRAPES TREATED IN SPRING OF 1958 AND PRUNED FEBRUARY 4, 1959

(Figures for first four sprayings are averages of five replicate vines and for the last two, averages of four replicate vines.)

\begin{tabular}{|c|c|c|c|c|c|c|}
\hline \multirow{2}{*}{$\begin{array}{l}\text { Treatment, concentration } \\
\text { of gibberellin }\end{array}$} & \multicolumn{6}{|c|}{ Date of spraying } \\
\hline & $4 / 15 / 58$ & $4 / 28 / 58$ & $5 / 9 / 58$ & $5 / 19 / 58$ & $5 / 28 / 58$ & $6 / 19 / 58$ \\
\hline$p p m$ & $l b$ & $l b$ & $l b$ & $l b$ & $l b$ & $l b$ \\
\hline 0 . & 5.8 & 6.5 & 4.4 & 5.6 & 5.3 & 6.3 \\
\hline $1 \ldots \ldots \ldots \ldots \ldots \ldots$ & $\ldots$ & $\ldots$ & $\ldots$ & $\ldots$ & 4.8 & 5.5 \\
\hline $\mathbf{5} \ldots \ldots \ldots \ldots \ldots \ldots \ldots \ldots$ & $\ldots$ & $\ldots$ & $\ldots$ & $\ldots$ & 5.5 & 6.0 \\
\hline $10 \ldots \ldots \ldots \ldots \ldots \ldots \ldots \ldots$ & 7.2 & 7.2 & 8.0 & 6.4 & $\ldots$ & $\ldots$ \\
\hline 25 . & 6.6 & 7.2 & 7.0 & 8.8 & 5.5 & 5.8 \\
\hline 50 . & 6.8 & 9.6 & 8.6 & 7.4 & 7.8 & 7.3 \\
\hline
\end{tabular}

L.S.D. at 5 per cent for concentrations at a given spraying date: sprayings 1 through $4,1.1 \mathrm{lb}$; sprayings 5 and $6,1.1 \mathrm{lb}$.

L.S.D. at 5 per cent for spraying dates at a given concentration: sprayings 1 through $4,1.0 \mathrm{lb}$; sprayings 5 and 6 , N.S.

TABLE 11

\section{AVERAGE NUMBER OF SHOOTS PER VINE OF CARIGNANE GRAPES SPRAYED IN SPRING OF 1958}

(Figures for first four sprayings are averages of five replicate vines and for the last two, averages of four replicate vines.)

\begin{tabular}{|c|c|c|c|c|c|c|}
\hline \multirow{2}{*}{$\begin{array}{l}\text { Treatment, concentration } \\
\text { of gibberellin }\end{array}$} & \multicolumn{6}{|c|}{ Date of spraying } \\
\hline & $4 / 15 / 58$ & $4 / 28 / 58$ & $5 / 9 / 58$ & $5 / 19 / 58$ & $5 / 28 / 58$ & $6 / 19 / 58$ \\
\hline \multirow{8}{*}{$\begin{array}{r}0 . \\
1 . \\
5 . \\
10 . \\
25 \\
50 .\end{array}$} & \multicolumn{6}{|c|}{ Shoots counted April 7, 1959} \\
\hline & 29 & 28 & 29 & 25 & 24 & 25 \\
\hline & .. & . & .. & .. & 28 & 27 \\
\hline & . & . & . & .. & 18 & 30 \\
\hline & 24 & 25 & 24 & 25 & .. & .. \\
\hline & 15 & 23 & 25 & 24 & 24 & 24 \\
\hline & 17 & 10 & 17 & 29 & 22 & 20 \\
\hline & \multicolumn{6}{|c|}{ Shoots counted April 20, 1959} \\
\hline $\ldots \ldots \ldots \ldots \ldots \ldots \ldots$ & 25 & 22 & 22 & 19 & .. & .. \\
\hline (a) & 27 & 23 & 28 & 21 & $\because$ & $\cdots$ \\
\hline 25. & 23 & 26 & 23 & 25 & .. & .. \\
\hline \multirow[t]{2}{*}{50 . } & 22 & 10 & 21 & 25 & . & . \\
\hline & \multicolumn{6}{|c|}{ Shoots counted May 7, 1959} \\
\hline $\mathbf{0}$. & 26 & 23 & 22 & 19 & .. & . \\
\hline $10 \ldots$ & 28 & 24 & 29 & 21 & . & .. \\
\hline $25 \ldots$ & 26 & 26 & 22 & 25 & $\ldots$ & $\ldots$ \\
\hline $50 \ldots$ & 24 & 15 & 21 & 25 & $\ldots$ & $\ldots$ \\
\hline
\end{tabular}

L.S.D. at 5 per cent for concentrations at a given spraying date: sprayings 1 through 4 counted $4 / 7 / 59,3.6$; counted $4 / 20 / 59,2.7$; counted $5 / 7 / 59,3.3$. Sprayings 5 and 6 , N.S.

L.S.D at 5 per cent for spraying dates at a given concentration: sprayings 1 through 4 counted 4/7/59, 3.3; counted $4 / 20 / 59,3.5$; counted $5 / 7 / 59,3.8$. Sprayings 5 and 6 , N.S. 
TABLE 12

AVERAGE NUMBER OF CLUSTERS PER VINE OF CARIGNANE GRAPES SPRAYED IN THE SPRING OF 1958

(Figures are averages of five replicate vines, counted April 13 and May 7, 1959.)

\begin{tabular}{|c|c|c|c|c|c|c|c|c|}
\hline \multirow{3}{*}{$\begin{array}{l}\text { Treatment, concentration } \\
\text { of gibberellin }\end{array}$} & \multicolumn{8}{|c|}{ Date of spraying } \\
\hline & \multicolumn{2}{|c|}{$4 / 18 / 58$} & \multicolumn{2}{|c|}{$4 / 28 / 58$} & \multicolumn{2}{|c|}{$5 / 9 / 58$} & \multicolumn{2}{|c|}{$5 / 19 / 58$} \\
\hline & $4 / 13 / 59$ & $5 / 7 / 59$ & $4 / 13 / 59$ & $5 / 7 / 59$ & $4 / 13 / 59$ & $5 / 7 / 59$ & $4 / 13 / 59$ & $5 / 7 / 59$ \\
\hline $\begin{array}{r}p p m \\
0 \ldots \ldots \ldots \ldots\end{array}$ & 51 & 40 & 49 & 42 & 45 & 40 & 39 & 35 \\
\hline $10 \ldots \ldots \ldots \ldots \ldots$ & 46 & 45 & 24 & 48 & 40 & 49 & 42 & 38 \\
\hline $25 \ldots$ & 23 & 40 & 28 & 46 & 28 & 41 & 36 & 45 \\
\hline $50 \ldots \ldots \ldots$ & 20 & 35 & 9 & 27 & 19 & 38 & 32 & 44 \\
\hline
\end{tabular}

L.S.D. at 5 per cent for concentrations at a given spraying date: counted 4/13/59,3.9; counted 5/7/59, 5.0. L.S.D. at 5 per cent for spraying dates at a given concentration: counted $4 / 13 / 59,6.3$; counted $5 / 7 / 59$, N.S.

TABLE 13

DATA ON THOMPSON SEEDLESS FRUIT HARVESTED IN 1958 AND 1959, SPRAYED IN JUNE OF 1957, 1958, 1959

(Figures are averages of four replicate vines.)

\begin{tabular}{|c|c|c|c|c|c|c|c|c|c|}
\hline $\begin{array}{c}\text { Treatment, } \\
\text { concentration of } \\
\text { gibberellin }\end{array}$ & $\begin{array}{l}\text { Condition } \\
\text { of vine }\end{array}$ & \multicolumn{2}{|c|}{$\begin{array}{l}\text { Average weight } \\
\text { fruit per vine }\end{array}$} & \multicolumn{2}{|c|}{$\begin{array}{c}\text { Average weight } \\
\text { per berry }\end{array}$} & \multicolumn{2}{|c|}{$\begin{array}{l}\text { Degrees } \\
\text { Balling }\end{array}$} & \multicolumn{2}{|c|}{$\begin{array}{l}\text { Total acid, per } \\
\text { cent tartaric }\end{array}$} \\
\hline$p p m$ & & $l b$ & $l b$ & $g m$ & $g m$ & & & & \\
\hline $0 \ldots$ & Trunk girdled & $\ldots$ & 28.8 & 2.26 & 3.09 & 23.0 & 21.1 & 0.74 & 0.48 \\
\hline & Not girdled & $\ldots$ & 32.1 & 1.91 & 2.62 & 23.2 & 22.6 & 0.73 & 0.46 \\
\hline 20 . & Not girdled & $\ldots$ & 37.1 & 2.71 & 2.89 & 18.9 & 21.4 & 0.83 & 0.51 \\
\hline 50. & Not girdled & $\ldots$ & 44.3 & 3.15 & 2.59 & 17.6 & 17.3 & 0.94 & 0.51 \\
\hline
\end{tabular}

The vines were pruned on February 4, 1959 (table 10). In many instances, brush weight was increased by gibberellin.

Shoot counts were taken at three different times in the spring of 1959 (table 11). Bud burst was usually markedly delayed in vines that received 10 to $25 \mathrm{ppm}$ gibberellin in the first three sprayings. Shoot count on vines that received $50 \mathrm{ppm}$ gibberellin in the second spraying was below normal on April 20 and May 7, 1959.

Cluster counts were made on April 13 and May 7 (table 12). Cluster emergence was delayed, especially by the first three sprayings. By May 7, however, cluster count was significantly lower than that of the controls only on vines that received $50 \mathrm{ppm}$ gibberellin in the first and second sprayings.

Fruit was harvested on September 26, 1959 (table 9). The 1959 crop was reduced more by the first three sprayings than was the 1958 erop. A single season evidently did not provide the vines enough time to recover. There was usually no significant difference between 1958 and 1959 in crops on vines of the last three sprayings. 
TABLE 14

AVERAGE WEIGHT OF PRUNING BRUSH PER VINE, AND AVERAGE

NUMBER OF SHOOTS AND CLUSTERS PER VINE OF THOMPSON

SEEDLESS GRAPES SPRAYED WITH GIBBERELLIN IN 1957

\begin{tabular}{|c|c|c|c|c|c|}
\hline \multirow{3}{*}{ Date of measurement } & \multicolumn{4}{|c|}{ Not girdled } & Girdled \\
\hline & \multicolumn{5}{|c|}{ Concentration gibberellin (ppm) } \\
\hline & 0 & 5 & 20 & 50 & 0 \\
\hline \multirow{4}{*}{$\begin{array}{l}3 / 4 / 58 . . \\
1 / 16 / 59\end{array}$} & \multicolumn{5}{|c|}{ Pruning weight (lb) } \\
\hline & $\begin{array}{l}5.3 \\
7.1\end{array}$ & $\begin{array}{l}7.6 \\
8.9\end{array}$ & 7.1 & 8.7 & 7.2 \\
\hline & & & & & \\
\hline & \multicolumn{5}{|c|}{ No. of shoots } \\
\hline \multirow[t]{2}{*}{ 4/9/59. } & 46 & 47 & 44 & 45 & 51 \\
\hline & \multicolumn{5}{|c|}{ No. of clusters } \\
\hline $6 / 3 / 58$ & 21.5 & 24.0 & 40.2 & 38.0 & 24.5 \\
\hline $4 / 9 / 59$. & 26.0 & 31.0 & 32.0 & 30.0 & 25.0 \\
\hline
\end{tabular}

\section{EFFECT OF GIBBERELLIN ON SEEDLESS GRAPES}

In the following experiments the same vines were sprayed over a period of two or three years to determine any cumulative injury from gibberellin. In one experiment, vines were sprayed in only one year, and were observed in the following year for any injury.

\section{Thompson Seedless}

When Thompson Seedless vines are sprayed after the shatter of berries, the increase in berry size is large, the amount depending on the concentration used (Weaver and McCune, 1959a, c). Prebloom applications elongate cluster parts somewhat.

Experiment No. 1. On June 10, 1957, after berry shatter, vines were cluster-thinned to five clusters per cane, and the remaining clusters were berry-thinned by removing the apical half (Winkler, 1931). The following day the vines were sprayed with concentrations of 5,20 , and $50 \mathrm{ppm}$, four vines per treatment. One set of vines was neither girdled nor sprayed, and another set was trunk-girdled but not sprayed (Jacob, 1931). These treatments were repeated on the same vines at the same developmental stage in June of 1958 and 1959.

Samples of the fruit from each treatment were taken at the harvests on August 26, 1957, and August 21, 1959. Pruning brush weights were obtained on March 14, 1958, and January 16, 1959. Shoot counts were taken on April 9, 1959. Cluster counts were taken on June 3, 1958, and April 9, 1959.

In 1957, gibberellin at 20 and $50 \mathrm{ppm}$ produced greatly enlarged berries (table 13). The increase was much less in 1959, but this may be accounted 


\section{TABLE 15}

DATA AT HARVESTS (AUGUST 25, 1958, AND AUGUST 19, 1959) FOR THOMPSON SEEDLESS GRAPES TREATED WITH GIBBERELLIN AT VARIOUS CONCENTRATIONS AND ON VARIOUS DATES IN 1958 (Figures are averages of five replicate vines.)

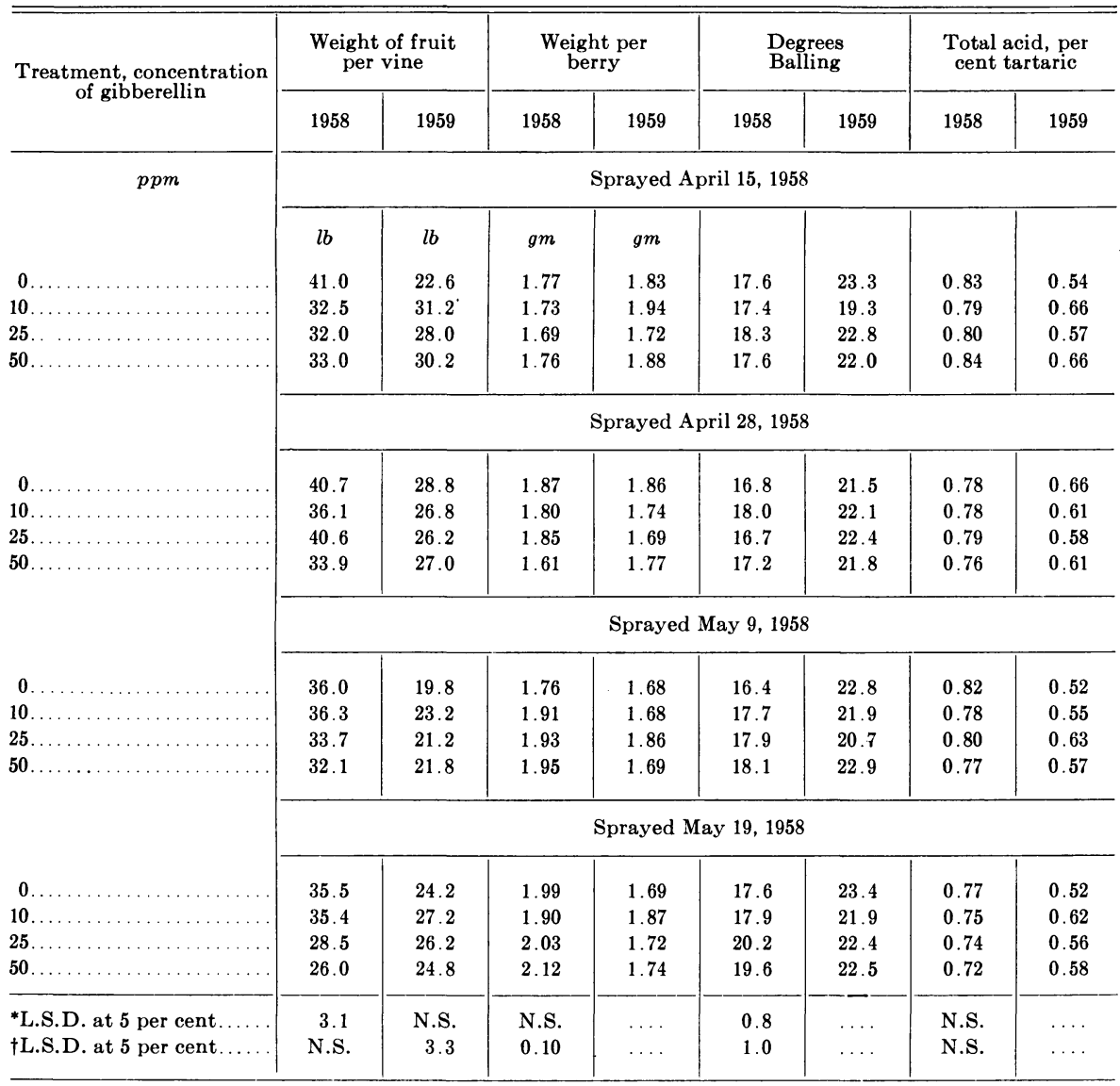

* Difference required for significance between concentrations on a given spraying date.

$\dagger$ Difference required for significance between spraying dates at a given concentration.

for by a heavy crop on the sprayed vines in that year. Fruit composition, as judged by degrees Balling and percentage of acid, was normal both in 1957 and 1959 (table 13 ).

On December 27, 1957, in the dormant season, one shoot was collected from each of the control and treated vines. A 6-inch segment from the middle portion and the basal 6-inch section, from each cane, were pooled for analysis. Since there was little or no difference in carbohydrate contents, the data are not presented.

In some instances pruning weights appeared to have increased after one or two seasons of spraying, but the differences were not significant (table 14). 
TABLE 16

PRUNING BRUSH WEIGHTS PER VINE, NUMBER OF SHOOTS AND

CLUSTERS OF THOMPSON SEEDLESS GRAPES TREATED

WITH GIBBERELLIN IN 1958

(Figures are averages of five replicate vines.)

\begin{tabular}{|c|c|c|c|c|}
\hline \multirow{2}{*}{$\begin{array}{c}\text { Treatment, concentration } \\
\text { of gibberellin }\end{array}$} & \multicolumn{4}{|c|}{ Date of sprayings } \\
\hline & $4 / 15 / 58$ & $4 / 28 / 58$ & $5 / 19 / 58$ & $6 / 11 / 58$ \\
\hline$p p m$ & \multicolumn{4}{|c|}{ Pruning weight (lb) $12 / 14 / 58$} \\
\hline 0 . & 8.1 & 9.5 & 6.4 & 7.4 \\
\hline $10 \ldots$ & 6.7 & 7.6 & 9.5 & 7.1 \\
\hline $25 \ldots \ldots$ & 7.3 & 7.5 & 8.0 & 9.1 \\
\hline $50 \ldots \ldots$ & 9.3 & 7.9 & 8.7 & 8.0 \\
\hline
\end{tabular}

L.S.D. at 5 per cent between concentrations on a given spraying date or between spraying dates at a given concentration is N.S.

\begin{tabular}{|c|c|c|c|c|}
\hline \multirow[b]{2}{*}{0 . } & \multicolumn{4}{|c|}{ No. of shoots $4 / 9 / 59$} \\
\hline & 52.8 & 42.4 & 44.8 & 50.0 \\
\hline 10. & 64.6 & 54.2 & 49.0 & 46.6 \\
\hline $\mathbf{2 5} \ldots \ldots \ldots \ldots \ldots \ldots$ & 51.6 & 59.2 & 32.8 & 40.0 \\
\hline $50 \ldots \ldots \ldots \ldots \ldots \ldots \ldots \ldots \ldots \ldots \ldots \ldots \ldots$ & 53.0 & 49.2 & 49.8 & 51.8 \\
\hline
\end{tabular}

L.S.D. at 5 per cent between concentrations on a given spraying date or between spraying dates at a given concentration is N.S.

\begin{tabular}{|c|c|c|c|c|}
\hline \multirow[b]{2}{*}{0} & \multicolumn{4}{|c|}{ No. of clusters $4 / 9 / 59$} \\
\hline & 28 & 38 & 29 & 34 \\
\hline $10 \ldots \ldots \ldots \ldots$ & 43 & 37 & 32 & 33 \\
\hline $25 \ldots \ldots \ldots$ & 39 & 38 & 32 & 44 \\
\hline$\ldots \ldots \ldots \ldots \ldots \ldots \ldots \ldots$ & 31 & 33 & 31 & 33 \\
\hline
\end{tabular}

L.S.D. at 5 per cent between concentrations on a given spraying date or between spraying dates at a given concentration is N.S.

Shoot and cluster counts were not depressed by gibberellin treatments (table 14). No injury was apparent even on vines sprayed at $50 \mathrm{ppm}$ during three successive years. Thus, gibberellin appears to be nontoxic to Thompson Seedless grapes.

Experiment No. 2. Prebloom sprays were applied in 1958, and crop weights and fruit analysis were determined in 1958 and 1959. Clusters were thinned to 20 per vine, but were not berry-thinned. Different vines were sprayed with gibberellin at $0,10,25$, or $50 \mathrm{ppm}$, five vines per treatment, on each of four dates: April 15, when shoots were $2 \frac{1}{2}$ to 4 inches long and clusters about 1/2 inch; April 28, when many shoots were 10 to 12 inches long, and clusters were 3 to 5 inches; May 9, when shoots were 18 to 36 inches long and clusters were 5 to 7 inches; and May 19, a few days before blooming began. A randomized split-plot arrangement was used.

In most cases crop weights decreased in 1958 (Weaver and McCune, $1959 c$ ) because of shot berry formation, but had returned to normal by 
1959 (table 15). Fruit quality, as indicated by berry size, degrees Balling, and percentage of acid, was normal in 1958 and 1959. Brush weights appear to have increased following the spraying in 1958, but the differences were not significant (table 16). The number of shoots and clusters emerging in 1959 was not significantly affected by gibberellin (table 16 ).

Experiment No. 3. On June 6, 1958, at berry shatter stage, an ungirdled Thompson Seedless vine was sprayed with gibberellin at 1,000 ppm. The same vine was similarly sprayed on May 28, 1959. Fruit harvests were on August 29, 1958, and August 21, 1959. In both seasons gibberellin enlarged the fruit greatly, but the vine appeared normal otherwise.

\section{Black Corinth}

An ungirdled Black Corinth vine was sprayed with gibberellin at $100 \mathrm{ppm}$ following flowering, on May 26, 1958, and again on May 28, 1959. Berry size and fruit composition in both years showed that the vine was not injured by spraying in two successive years. Except for the very large berries, the vine appeared normal.

\section{DISCUSSION}

The seeded and seedless varieties studied differ strikingly in susceptibility to injury from gibberellin. The seeded varieties were often severely injured by high concentrations, such as $50 \mathrm{ppm}$, whereas Thompson Seedless and Black Corinth withstood gibberellin at $1,000 \mathrm{ppm}$ or $100 \mathrm{ppm}$, respectively, with no apparent ill effect. More varieties must be tested, however, before a definite conclusion can be drawn with respect to differences between seeded and seedless varieties.

Previously noted differences show that girdling shortly after flowering greatly enlarges seedless grapes, but has little effect on the seeded varieties (Jacob, 1931). In contrast, thinning increases the berry size of seeded grapes but ordinarily has little effect on that of seedless grapes (Winkler, 1953). Naturally occurring gibberellin has been detected in seedless, but not in seeded, varieties (Coombe, 1960).

In seeded varieties, high concentrations of gibberellin are injurious to vegetative growth as well as to the fruit (Weaver and McCune, 1959a). For example, it has been shown that the shoots and canes of Zinfandel split and crack. In the present experiments many seeded vines sprayed with gibberellin at 5 or $25 \mathrm{ppm}$ showed delayed bud break in the following spring. In some cases buds were killed. It has been suggested that, in regions where frosts occur following leafing out, some delay as a result of gibberellin sprays might be advantageous (Weaver, 1959; Rives and Pouget, 1959; Alleweldt, 1960).

In no instances were vines completely killed by gibberellin, and in nearly all cases even severely injured vines returned to a normal yield within two seasons of being sprayed. One season was usually insufficient for complete recovery.

It is fortunate that low concentrations (1 to $10 \mathrm{ppm}$ ) of gibberellin applied at prebloom stage are usually enough to loosen wine grapes (the authors, unpublished data). Varietal differences between seedless and seeded grapes 
in their reaction to gibberellin are greater than differences among seeded varieties only.

Weight of pruning brush was sometimes increased by the gibberellin sprays. This would be accounted for partly by increased shoot growth (Weaver and McCune, 1959a) and partly by a decreased crop in the year of spraying. When the crop is light, more of the vine's energy is channeled into vegetative growth (Winkler, 1931). It remains to be seen whether the increased growth is at the expense of carbohydrate reserves in the roots.

\section{SUMMARY}

In 1957, different vines of Zinfandel, Red Malaga, Tokay, and Ribier grapes were sprayed at each of four developmental stages with gibberellin in a range of 0 to $25 \mathrm{ppm}$. In 1958 and 1959, the effects on cropping, vine vigor, and spring foliation were followed to note the degree of recovery of vines injured by gibberellin. Higher concentrations injured the seeded varieties, as shown by decreased crop weight and delayed foliation in the spring. In some instances buds were killed. Weight of pruning brush was sometimes increased by gibberellin. Two seasons were usually required for vines to return to normal crop weights, pruning brush weights, spring foliation, and cluster counts.

In another experiment, Zinfandel and Carignane vines were sprayed with gibberellin in 1958, and vine behavior was followed in 1959. Results were similar to those obtained in the experiments begun in 1957.

Thompson Seedless vines were sprayed in a range of 0 to $50 \mathrm{ppm}$ for three successive years, and one vine was sprayed at $1,000 \mathrm{ppm}$ following flowering in two consecutive years. Other vines were sprayed at prebloom stage with gibberellin in the range of 0 to $50 \mathrm{ppm}$. In no instances did injury result. A Black Corinth vine was uninjured by being sprayed in two successive years with gibberellin at $100 \mathrm{ppm}$. Thus, gibberellin was very toxic to the seeded grapes studied, but nontoxic to the seedless.

Carbohydrate analyses of basal portions of eanes in the dormant season showed that gibberellin caused little or no change in the percentage of sugar or starch in seeded or seedless grapes. The carbohydrate content of cluster frameworks of Zinfandel was increased, however.

\section{LITERATURE CITED}

ALLEW ELDT, G.

1960. Austriebshemmung und- förderung der Winterknospen von Reben durch Gibberellinsäure und Rindite. Weinwiss. No. 1.

CoOmbe, B. G.

1960. Relationship of growth and development to changes in sugars, auxins, and gibberellins in fruit of seeded and seedless varieties of Vitis vinifera. Plant Physiol. $35(2): 241-50$.

ЈАСОВ, Н. E.

1931. Girdling grape vines. California Agr. Ext. Cir. 56.

PhILLIPS, T. G.

1941. Semimicro method for determining copper reduced by sugars. Assoc. Off. Agr. Chem. Jour. $24: 181-83$. 
Rives, M., and R. Pouget

1959. Action de la gibberelline sur la dormance de la vigne (Vitis vinifera L.). Compt. Rend. Acad. Sci. France 248:3600-602.

WEAVER, R. J.

1957. Gibberellins on grapes. The Blue Anchor 34(4):10-11.

1959. Prolonging dormancy in Vitis vinifera with gibberellin. Nature 183:1198.

WEAVER, R. J., and S. B. MCCunE

1959a. Response of certain varieties of $V$ itis vinifera to gibberellin. Hilgardia 28(13): $297-350$.

$1959 b$. Effect of gibberellin on seeded Vitis vinifera, and its translocation within the vine. Hilgardia 28(20):625-45.

$1959 c$. Effect of gibberellin on seedless Vitis vinifera. Hilgardia 29(6):247-75.

WINKLER, A. J.

1931. Pruning and thinning experiments with grapes. Calif. Agr. Exp. Sta. Bul. 519.

1953. Producing table grapes of better quality. The Blue Anchor $30(1): 28-31$.

WINKLER, A. J., and W. O. WILLIAMS

1945. Starch and sugars of Vitis vinifera. Plant Physiol. 20:412-32. 
The journal Hilgardia is published at irregular intervals, in volumes of about 600 pages. The number of issues per volume varies.

Subscriptions are not sold. The periodical is sent as published only to libraries, or to institutions in foreign countries having publications to offer in exchange.

You may obtain a single copy of any issue free, as long as the supply lasts; please request by volume and issue number from:

\author{
Agricultural Publications \\ 207 University Hall \\ 2200 University Avenue \\ Berkeley 4, California
}

The limit to nonresidents of California is 10 separate issues on a single order. A list of the issues still available will be sent on request.

In our publications it is sometimes convenient to use trade names of products or equipment rather than scientific identifications. In so doing it is unavoidable in some cases that similar products which are on the market under other trade names may not be cited. No endorsement of named products is intended nor is criticism implied of similar products which are not mentioned. 

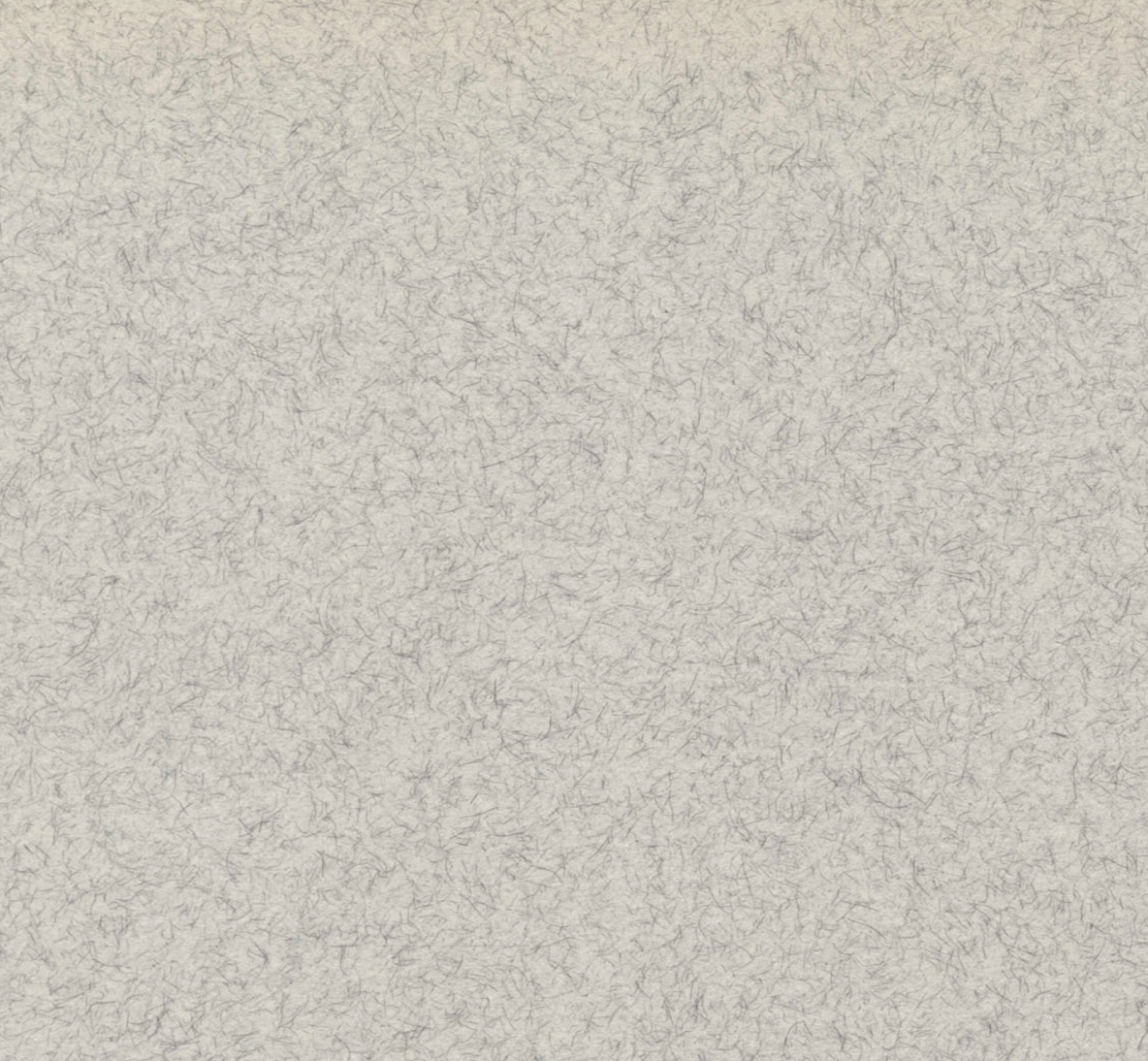

$\frac{3}{4}$

$\cos ^{4}$
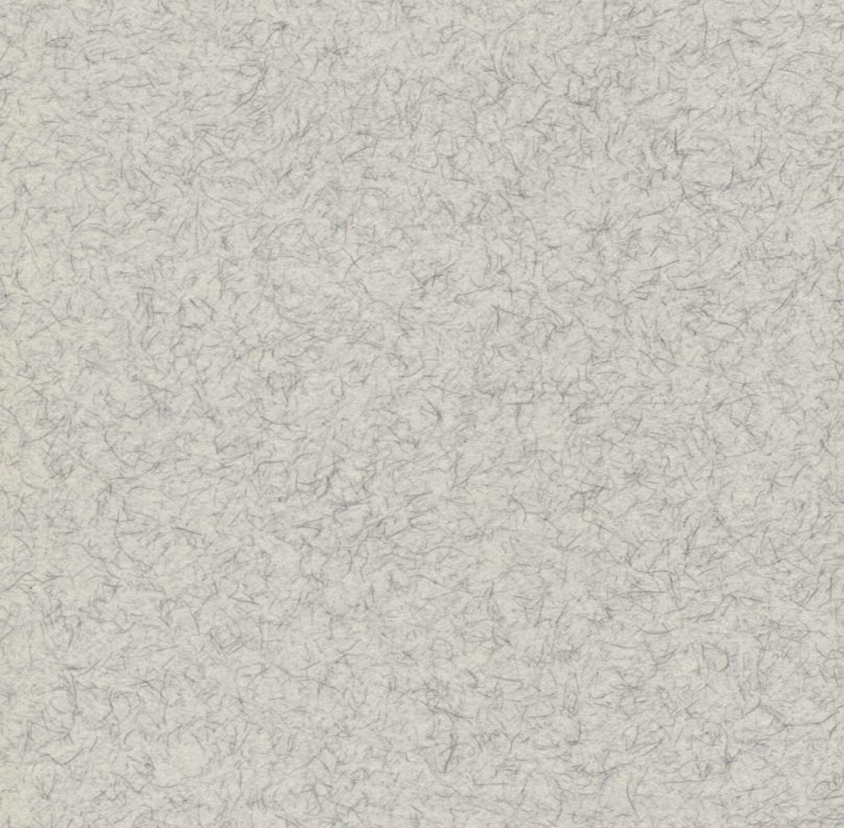

W.

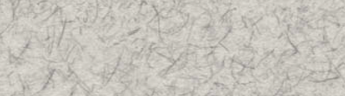
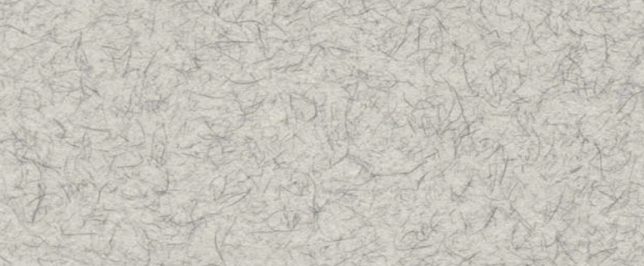

-1
-2

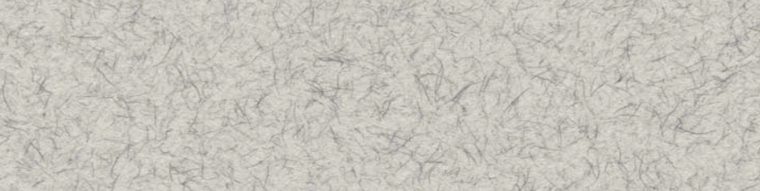

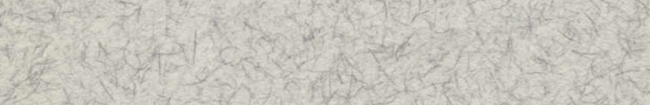

1.t. कीजे

$=1$

$x+\frac{1}{2}$

(1) 